\title{
The most common isolated microorganisms and its clinical manifestation in hospitalised women suffering from urogenital diseases in Latvia
}

\author{
Anatolijs Naumčiks*, Elvīra Turoka
}

Department of Medicine, Riga Stradins University, Riga, Latvia

Received: 29 June 2015

Accepted: 22 July 2015

\author{
*Correspondence: \\ Dr. Anatolijs Naumčiks, \\ E-mail: anatol.naumchix@gmail.com
}

Copyright: (C) the author(s), publisher and licensee Medip Academy. This is an open-access article distributed under the terms of the Creative Commons Attribution Non-Commercial License, which permits unrestricted non-commercial use, distribution, and reproduction in any medium, provided the original work is properly cited.

\begin{abstract}
Background: The monitoring of genital tract infections, especially sexually transmitted infections, is a vital part of health priority in many countries. One of the most common vaginal infections in women of childbearing age is bacterial vaginosis.

Methods: This is a laboratory based retrospective study. We analysed 774 patients' cases (age range 18-35 years). Patients were subcategorized into three groups: patients with inflammation in genital tract, patients without inflammatory processes in genital tract, threatened abortion women. Laboratory tests also were divided depending on the type of examination.

Results: There were 49 patients in the first group, 60 women in the second group and 236 pregnant women with threatened abortion in the third group. Gram negative bacteria (Escherichia coli and Enterococcus spp.) were the most common isolated bacteria in the first and second group. Coagulase-negative staphylococci were predominant in the third group. Streptococcus agalactiae was isolated in $11.8 \%$ cases. In our study, Trichomonas vaginalis infection was found in $1.2 \%$.

Conclusions: The most common isolated bacteria were Coagulase-negative staphylococci and gram negative bacteria. Ureaplasma urealyticum was detected in a decisive majority (38.9\%) of Mycoplasma species infections. In the first patients group - women with inflammatory process in genital tract were not found 3 bacteria, opposite to the second and third group.
\end{abstract}

Keywords: Genital infections, Streptococcus agalactiae, Sexual and reproductive health

\section{INTRODUCTION}

The monitoring of genital tract infections, especially sexually transmitted infections, is a vital part of health priority in many countries. ${ }^{1,2}$ The early detection of asymptomatic people in the community is very important. Screening may help to reduce morbidity and mortality from communicable diseases and it is urgent of public health. ${ }^{3}$

One of the most common vaginal infections in women of childbearing age is bacterial vaginosis (BV), it is found in 40 to 50 percent of cases. ${ }^{4,5}$ It is caused by reduction in concentration of the normally dominant Lactobacilli and an increase in concentration of other organisms, especially anaerobic gram negative rods.

In pregnancy, lower genital tract infections can be associated with complications both to the mother and the neonate. Vaginal infection represents important risks factors for complications of pregnancy such as premature rupture of membrane, preterm labour and birth, perinatal infection. For example, Streptococcus agalactiae may cause severe pneumonia, meningitis in neonates and remains one of the most often cause of neonatal sepsis. ${ }^{6}$ The risk of death is higher in older infants than it is in 
neonates. Even with appropriate treatment, neonatal infections with Streptococcus agalactiae have a $20 \%$ mortality rate. ${ }^{7,8} 10-30 \%$ of women have colonization with Group B streptococci in their genital tracts. Whereas the bacterium is normally a resident of the gastrointestinal tract. ${ }^{7}$ About $2 \%$ of all infants are infected by Streptococcus agalactiae, but only $25 \%$ of infants exposed are colonized with clinical signs of infection..$^{7,8}$

Pathological discharge in women of reproductive age is usually caused by infection and causative organisms may or may not be sexually transmitted. Clinically genital tract infection can manifest both as symptomatic and asymptomatic infection.

We therefore conducted an observation of reproductive tract infections and sexually transmitted infections prevalence in one of the hospitals in Latvia.

\section{METHODS}

This is a laboratory based retrospective study. We analyzed 774 patients' cases (mean age 26.5 years, range 18-35 years), all the patients were treated in Gynaecology and Maternity Care center, Paul's Stradins Clinical University Hospital in Riga. Patients were subcategorized into three groups:

1. Patients with inflammation in genital tract.

2. Patients without inflammatory processes in genital tract disease.

3. Threatened abortion women.

Laboratory tests also were divided into three groups.
1. Microscopic examination of vaginal discharge specimens. Wet mounted film was used for detecting Trichomonas vaginalis, Candida albicans, Neisseria gonorrhoeae, Gardnerella vaginalis, Mobiluncus spp., leucocytes and epithelial cells. Gram stained film was prepared to detect yeast, bacteria, pus cells and clue cells.

2. Analysis for Ureaplasma urealyticum and Mycoplasma hominis species. The pathogenic colonization was considered if $>10 \mathrm{cfu} / \mathrm{ml}$.

3. Microbiological examination - vaginal swabs were cultured on the different culture media (blood agar, chocolate agar, MacConkey agar).

The study protocol was approved by the Local Ethics Committee of Riga Stradins University and Paul's Stradins Clinical University Hospital.

The results were analysed using Open Office 4.0.0. and statistical package program SPSS 20. In testing hypotheses Mann-Whitney U-test was used, for all tests, $\mathrm{p}<0.05$ is considered significant.

\section{RESULTS}

49 patients in the first group - women with inflammation process in the genital tract, were examined for pathogenic microorganisms using one or more laboratory tests. Laboratory tests were divided as described previously. Wet mounted film was used in 29 patients (59.2\%). Only $6(20.7 \%)$ sample were positive and it followed by Candida albicans 2 (33.3\%), Gardnerella vaginalis 2 (33.3\%), Trichomonas vaginalis 1 (16.7\%), Mobiluncus spp. $1(16.7 \%)$.

Table 1: Microbiological examination.

\begin{tabular}{|c|c|c|c|}
\hline & $\begin{array}{l}\text { Patients with infection in genital } \\
\text { tract } \mathrm{N}=\mathbf{3 3}(\%)\end{array}$ & $\begin{array}{l}\text { Patients non-infectious genital tract } \\
\text { disease } N=20(\%)\end{array}$ & $\begin{array}{l}\text { Threatened abortion } \\
\mathbf{N}=91(\%)\end{array}$ \\
\hline Enterococcus spp. & $5(17.2)$ & 7 (38.9) & $28(34.6)$ \\
\hline E.coli & $10(34.5)$ & $8(44.4)$ & $19(23.5)$ \\
\hline CoNS & $11(37.9)$ & $3(16.7)$ & $39(48.1)$ \\
\hline S.agalactiae & $3(10.3)$ & $2(11.1)$ & $12(14.8)$ \\
\hline S. aureus & $4(13.8)$ & $3(16.7)$ & $2(2.5)$ \\
\hline S. pyogenes & $1(3.4)$ & $1(5.6)$ & $0(0.0)$ \\
\hline K. pneumoniae & $0(0.0)$ & $0(0.0)$ & $4(4.9)$ \\
\hline A. baumanii & $0(0.0)$ & $0(0.0)$ & $1(1.2)$ \\
\hline 1 bacterium & $24(82.8)$ & $13(72.2)$ & $60(74.1)$ \\
\hline 2 bacteria & $5(17.2)$ & $4(22.2)$ & $18(22.2)$ \\
\hline 3 bacteria & $0(0.0)$ & $1(5.6)$ & $3(3.7)$ \\
\hline Negative culture & $4(12.1)$ & $2(10.0)$ & $10(11.0)$ \\
\hline
\end{tabular}


Analysis for Urea plasma urealyticum and Mycoplasma hominis species was made in $29(59.2 \%)$ patients. 22 $(75.9 \%)$ samples were positive. More often was isolated Ureaplasma urealyticum $16(72.7 \%)$ than Mycoplasma hominis $6(27.3 \%)$.

Microbiological examination was performed in 33 $(67.3 \%)$ patients. In $29(87.9 \%)$ samples the result was positive. In the majority of cases $24(82.8 \%)$ was found one bacterium and in 5 cases $(17.2 \%)$ were found 2 bacteria. Type of bacteria and frequency are shown below (Table 1).

Second group consists of patients with non-inflammatory genital tract diseases (ovulatory dysfunction, polycystic ovaries, endometriosis etc.). There were examined 60 women in this group. Wet mounted film was obtained in $44(73.3 \%)$ patients and only $10(22.7 \%)$ samples were positive. In $5(50.0 \%)$ cases Candida albicans was found, but 3 patients did not have complained of vaginal discharge and clinical symptoms. Candida spp. is normally present in $25-50 \%$ of healthy females. ${ }^{9}$ To determine whether Candida species are becoming pathogenic, 2 criteria were observed: the presence of vaginal discharge and the presence of budding yeast cells or pseudo-hyphae in direct microscopy. In other sample were 2 Gardnerella vaginalis and 3 Mobiluncus spp. Trichomonas vaginalis was not found in any sample comparing with the first group patients.

Ureaplasma urealyticum and Mycoplasma hominis analysis was taken in 33 patients and only 9 were positive with Ureaplasma predominance $8(88,9 \%)$ versus Mycoplasma $1(11.1 \%)$.

From 60 patients microbiological examination was performed in $20(33.3 \%)$ women and 18 (90.0\%) tests were positive. It shows that the test was made with a high precision. In $13(72.2 \%)$ cases was isolated one bacterium, in $4(22.2 \%)$ cases- 2 bacteria and in $1(5.6 \%)$ case 3 bacteria. The most common isolated bacteria in this group are Escherichia coli 8 (44.4\%) and Enterococcus spp. 7 (38.9\%). Other microorganisms are shown below (Table 1).

In the assessment of third patient group - 236 pregnant women with threatened abortion were included. Wet mounted film was performed in 187 patients. Only 37 $(19.8 \%)$ were positive. It reveals higher prevalence of Gardnerella vaginalis $14(37.8 \%)$ and Candida albicans $13(35.1 \%)$ in addition to Mobiluncus spp. $8(21.6 \%)$ and Trichomonas vaginalis $2(5.4 \%)$.

128 analyses for Ureaplasma urealyticum and Mycoplasma hominis were taken in this studying group. Positive result was found in 58 (45.3\%) patients. Ureaplasma urealyticum appear the most common 50 $(86.2 \%)$ in comparison with Mycoplasma hominis 8 $(13.8 \%)$.
Microbiological examination was performed in 91 patients and $81(89.0 \%)$ of them had positive culture. Klebsiella pneumoniae was isolated from 4 (4.9\%) of the pregnant women and none $(0 \%)$ from the non-pregnant women. Coagulase-negative staphylococci (CoNS) 39 (48.1\%) and Enterococcus spp. 28 (34.6\%) appear the most common isolated bacteria in this group.

\section{DISCUSSION}

Of the 190 study women, $74(38.9 \%)$ had Ureaplasma urealyticum and 15 (7.9\%) Mycoplasma hominis infection. There was an obvious disproportion in the incidence of these two Mycoplasma species. The results confirmed the observation made by other authors that Ureaplasma urealyticum was detected in a decisive majority of infections. ${ }^{10}$

We found the highest percentage of positive cultures in patients with inflammatory genital tract diseases. Bhandari et al. detected the presence of Ureaplasma urealyticum in $56 \%$ of chronic cervicitis women and in $38 \%$ of the cases this pathogen was the only one. ${ }^{11}$

Despite ongoing debate, the evidence that Mycoplasma cause lower genital tract disease in women remains sparse. $^{12}$ However, it is then unclear whether rapid multiplication of these organisms provides an environment conducive to the multiplication of other bacterial species, such as anaerobic gram-negative rods and gram-positive cocci, and then finally Gardnerella vaginalis and Mycoplasma hominis. ${ }^{13}$

In the first and third patients group the most common isolated bacteria were Coagulase-negative staphylococci (CoNS) and gram negative bacteria, Escherichia coli and Enterococcus spp. respectively. CoNS colonization in the genitourinary system is considered as a normal part of vaginal microflora, but women with CoNS colonization are more likely to have experienced a urinary tract infection. ${ }^{14}$ In the first patients' group women with an inflammatory process in genital tract were not found 3 bacteria, opposite to the second and third groups. It can point to the absolutely pathogenic nature of isolated microorganisms in the patients with inflammatory processes in genital tract. Neisseria gonorrhoeae is not found in any patients groups. Viral infections require sophisticated techniques for isolation which were not available at the time of this study.

Streptococcus agalactiae was isolated in $11.8 \%$ cases. Group B streptococcus (Streptococcus agalactiae) is a frequent colonizer of the female perigenital area and is recognised as the most frequent cause of severe early onset infection in newborn infants. ${ }^{15}$

In our study, Trichomonas vaginalis infection was found in $1.2 \%$ of patients only and it is contrast to other authors. ${ }^{16}$ Trichomoniasis is a sexually transmitted disease (STI) with important public health ramifications. 
It has been associated with vaginitis, cervicitis, urethritis, and pelvic inflammatory disease (PID).

Funding: No funding sources

Conflict of interest: None declared

Ethical approval: The study was approved by the Local Ethics Committee of Riga Stradins University and Paul's Stradins Clinical University Hospital

\section{REFERENCES}

1. Over M, Piot P. HIV infection and sexually transmitted diseases. In: Jamison DT, Mosley WH, Measham AR, Bobadilla J-L editors. Disease control priorities in developing countries. New York: Oxford University Press; 1993.

2. World Bank. World development report 1993: investing in health. New York: Oxford University Press; 1993.

3. Nsagha DS, Bello CSS, Kandakai-Olukemi YT. Maternal carriage in pregnancy of group B streptococcus in Jos: Relation of endo-cervical and anorectal colonization. Nig Q J Hosp Med. 1997;7(1):53-6.

4. Morris M, Nicoll A, Simms I, Wilson J, Catchpole M. Bacterial vaginosis: a public health review. 2001;108(5):439-50.

5. Tolosa JE, Chaithongwongwatthana S, Daly S, Maw WW, Gaitán H, Lumbiganon P et al. International Infections in Pregnancy (IIP) study: variations in the prevalence of bacterial vaginosis and distribution of morphotypes in vaginal smears among pregnant women. Am J Obstet Gynecol. 2006;195(5):1198204.

6. Brimil N, Barthell E, Heindrichs U, Kuhn M, Lütticken R, Spellerberg B. Epidemiology of Streptococcus agalactiae colonization in Germany. Int J Med Microbiol. 2006;296(1):39-44.

7. Ryan, K. J., \& Ray, C. G. (Eds.). Sherris Medical Microbiology: An Introduction to Infectious Disease. (Fourth Edition. ed.). New York. McGraw-Hill 2004.

8. Koenig JM, Keenan WJ. Group B streptococcus and early-onset sepsis in the era of maternal prophylaxis. Pediatric Clinics of North America. 2009;56(3):689708.
9. Samia S. Khamees Characterization of vaginal discharge among women complaining of genital tract infection Omar Al-Mukhtar University, Tobruk, Lybia [Khamees, 3(10): Oct., 2012] ISSN: 09767126.

10. Zdrodowska- Stefanow B, Kłosowska WM, Ostaszewska-Puchalska I, Bułhak-Kozioł V, Kotowicz B. Ureaplasma urealyticum and Mycoplasma hominis infection in women with urogenital diseases. Adv Med Sci. 2006;51:250-3.

11. Bhandari H, Malhotra S, Sharma M, Kumar B. Microbial flora in women with chronic cervicitis. Journal of the Indian Medical Association. 2000; 98:384-6.

12. Maruška Marovt, Darja Keše, Jovan Miljković, Mojca Matičič Clinical role of Urea plasma parvum and Urea plasma urealyticum presence in female lower urogenital tract: Is there a place for routine screening and treatment? Zdrav Vestn 2014; 83:62937.

13. Isobel J. Rosenstein, D. J. Morgan, Marie Sheehan, R. F. Lamont .f. And D. Taylor- Robinson. Bacterial vaginosis in pregnancy: distribution of bacterial species in different gram-stain categories of the vaginal flora. . Med Microbiol. 1996;45:120-6.

14. Rupp ME1, Soper DE, Archer GL. Colonization of the female genital tract with Staphylococcus saprophytic us. J Clin Microbiol. 1992;30(11):29759

15. Montero Alonso R, Barbadillo Izquierdo F, Ansó Oliván S, Marrero Calvo M, Carpintero Martín I, Sastre Huerta E et al. [Neonatal sepsis caused by Streptococcus agalactiae. What should be done?]. An Esp Pediatr. 1998;48(3):288-92.

16. Madeline Sutton, Maya Sternberg, Emilia $H$. Koumans, Geraldine McQuillan, Stuart Berman and Lauri Markowitz The Prevalence of Trichomonas vaginalis Infection among Reproductive-Age Women in the United States, 2001-2004. Clin Infect Dis. 2007;45(10):1319-26.

Cite this article as: Naumčiks A, Turoka E. The most common isolated microorganisms and its clinical manifestation in hospitalised women suffering from urogenital diseases in Latvia. Int $\mathbf{J}$ Reprod Contracept Obstet Gynecol 2015;4:959-62. 